\title{
Identification of androgen-dependent glycoproteins in the hamster epididymis and their association with
}

\section{spermatozoa}

\author{
Fernanda M. González Echeverria, Patricia S. Cuasnicú and J. A. Blaquier \\ Instituto de Biologia y Medicina Experimental, Laboratorio de Esteroides, Obligado 2490, \\ 1428 Buenos Aires, Argentina
}

\begin{abstract}
Summary. Androgen-dependent epididymal proteins were investigated in the hamster. The stimulation of labelled amino acid incorporation, as well as the colour intensity of bands stained with Coomassie Blue after electrophoresis of the epididymal cytosol from castrated animals with and without androgen replacement, were used as semi-quantitative criteria for evaluation. These techniques allowed the identification of 6 androgen-sensitive bands (EP) with the following relative electrophoretic mobilities with respect to albumin: $\mathrm{EP}_{1}=0.8 ; \mathrm{EP}_{2}=1.11 ; \mathrm{EP}_{3}=$ $1 \cdot 21 ; \mathrm{EP}_{4}=1 \cdot 31 ; \mathrm{EP}_{5}=1 \cdot 52 ; \mathrm{EP}_{6}=1.63$.

The proteins $\mathrm{EP}_{1}, \mathrm{EP}_{3}$ and $\mathrm{EP}_{4}$ were also found in fluid from the cauda epididymidis. Extraction of spermatozoa from the distal corpus and cauda epididymidis with 0.25 and $0.5 \mathrm{M}-\mathrm{NaCl}$ yielded appreciable amounts of $\mathrm{EP}_{2}$ and $\mathrm{EP}_{3}$ but these bands were not detected in extracts of spermatozoa from proximal segments. The approximate molecular weights were 61400 for $\mathrm{EP}_{1}, 42500$ for $\mathrm{EP}_{2}$, 23800 for $\mathrm{EP}_{3}, 20400$ for $\mathrm{EP}_{4}, 26100$ for $\mathrm{EP}_{5}$ and 41000 for $\mathrm{EP}_{6}$. All bands stained as glycoproteins with periodic acid-Schiff reagent.
\end{abstract}

\section{Introduction}

Although the intimate nature of the changes undergone by spermatozoa during maturation is still unknown, there is enough proof to demonstrate that this process is androgen-dependent (reviewed by Orgebin-Crist, Danzo \& Davies, 1975) and mediated by factors produced by the epididymis (reviewed by Bedford, 1975).

An increasing body of evidence points to secreted epididymal proteins as being essential for this process. On the one hand, androgen-induced maturation of rabbit spermatozoa in culture can be blocked by protein and RNA synthesis inhibitors (Orgebin-Crist \& Jahad, 1978) and, moreover, the effect of androgens in this system can be reproduced by a steroid-free epididymal extract (Orgebin-Crist \& Jahad, 1979). On the other hand, secretory epididymal proteins, especially glycoproteins, have been shown to interact with maturing spermatozoa of the rat (Cameo \& Blaquier, 1976; Lea, Petrusz \& French, 1978; Olson \& Hamilton, 1978; Kohane, Cameo, Piñeiro, Garberi \& Blaquier, 1980), ram (Voglmayr, Fairbanks, Jackowitz \& Colella, 1980), rabbit and hamster (Moore, 1980). Such an interaction could explain the changes in antigenicity (Hunter, 1969; Barker \& Amann, 1971; Johnson \& Hunter, 1972; Killian \& Amann, 1973), lectin binding sites (Nicolson, Usui, Yanagimachi, Yanagimachi \& Smith, 1977) and surface charge (Bedford, 1963; Cooper \& Bedford, 1971; Yanagimachi, Noda, Fujimoto \& Nicolson, 1972; Moore, 1979) that are known to occur in the maturing spermatozoon. 
For the hamster the only report of such activities is that of Moore (1980) who has described the existence of three acidic glycoproteins in cauda epididymal fluid and the adsorption of at least one of these moieties to spermatozoa. We have investigated the androgen-dependent proteins of the hamster epididymis and their binding relationship to spermatozoa.

\section{Materials and Methods}

Adult golden hamsters (Mesocricetus auratus) were used. When necessary, the animals were castrated under ether anaesthesia. Testosterone was administered at a dose of $0.3 \mathrm{mg}$ as a single daily s.c. injection. Mixtures of ${ }^{14} \mathrm{C}$ - and ${ }^{3} \mathrm{H}$-labelled amino acids were purchased from New England Nuclear (Boston, Massachusetts, U.S.A.). Soybean trypsin inhibitor, bovine serum albumin and ovalbumin were from Sigma Chemical Co. (St Louis, Missouri, U.S.A.). Testosterone microcrystals were obtained from Laboratorios Gador (Buenos Aires, Argentina). All other reagents were of analytical grade.

Immediately after death the organs were dissected out, weighed, minced and homogenized in 3 volumes of $50 \mathrm{mM}$-Tris buffer, $\mathrm{pH} 7 \cdot 8$, containing $0.25 \mathrm{M}$-sucrose, $15 \mathrm{~mm}$-EDTA and 0.25 mM-dithiothreitol. The homogenates were centrifuged at $105000 \mathrm{~g}$ for $60 \mathrm{~min}$ to obtain the cytosol fractions. Fluid from the cauda epididymidis was obtained by cannulation of the vas deferens and retrograde washing of its contents. Spermatozoa were removed by centrifugation and the supernatant was separated.

Extraction of spermatozoa. Testicular spermatozoa were obtained by puncture of the dilated rete testis of animals in which the efferent ducts had been ligated $24 \mathrm{~h}$ previously. Epididymal spermatozoa were obtained by cutting the caput, corpus and cauda regions in $1 \mathrm{ml}$ PBS (0.140

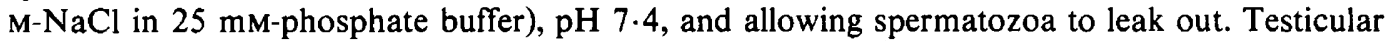
and epididymal spermatozoa were washed twice by suspension and centrifugation in PBS. The pellet was then re-suspended in PBS made 0.25 or $0.5 \mathrm{M}$ with respect to $\mathrm{NaCl}$ and incubated at room temperature for $20 \mathrm{~min}$ in a shaker. After centrifugation the supernatant was separated and analysed further.

Electrophoresis. Aliquots of the cytosol fractions or sperm extract, containing $75 \mu \mathrm{g}$ protein, were electrophoresed in $10 \%$ polyacrylamide gel slabs $(10.5 \times 8.2 \times 0.3 \mathrm{~cm})$ using 5 mM-Tris-38 mM-glycine, $\mathrm{pH} 8 \cdot 3$, as electrode buffer. The gels were stained with Coomassie Blue or with periodic acid-Schiff reagent by the method described by Zacharius, Zell, Morrison \& Woodlock (1969). Molecular weights were estimated by the linear regression analysis method of Ferguson (Rodbard \& Chrambach, 1974) with gel concentrations of 7.5, 10, 12 and $14 \%$. The standard proteins used for calibration were bovine serum albumin (67 000), ovalbumin (43 500) and soybean trypsin inhibitor (22 700).

To test the influence of androgens on protein synthesis we followed the technique described by Katzenellenbogen \& Gorski (1975). Epididymides from castrated animals, with and without androgen treatment, were minced and incubated with $40 \mu \mathrm{Ci}{ }^{3} \mathrm{H}$-labelled amino acid mixture or $15 \mu \mathrm{Ci}{ }^{14} \mathrm{C}$-labelled amino acid mixture, respectively, for $3 \mathrm{~h}$ at $31^{\circ} \mathrm{C}$ in Krebs-Ringerphosphate buffer, pH 7.4. After extensive washing, the tissues were homogenized and the cytosol fraction obtained. Aliquots from each cytosol were mixed and co-electrophoresed. The gels were sliced at $1 \mathrm{~mm}$ intervals, dissolved in $100 \mu \mathrm{l} 30 \% \mathrm{H}_{2} \mathrm{O}_{2}$ and the radioactivity determined. Results are expressed as the ratio ${ }^{3} \mathrm{H}:{ }^{14} \mathrm{C}$ in each band.

Protein was quantified according to the method of Lowry, Rosebrough, Farr \& Randall (1951). Spermatozoa were counted using a haemocytometer. 


\section{Results}

The initial experiments for the identification of epididymal androgen-dependent proteins were performed using the differential incorporation of labelled amino acids into protein by epididymides of castrated hamsters with $\left({ }^{3} \mathrm{H}\right.$-label) and without $\left({ }^{14} \mathrm{C}\right.$-label) subsequent androgen treatment. The results are shown in Text-fig. 1. Consistently elevated incorporation of ${ }^{3} \mathrm{H}$-labelled amino acids by tissues from androgen-treated animals was detected in 6 areas. These were designated as epididymal protein (EP) bands 1-6 and their electrophoretic mobilities relative to albumin $(R \mathrm{a})$ in $10 \%$ acrylamide gels were $\mathrm{EP}_{1}=0.8 ; \mathrm{EP}_{2}=1 \cdot 11 ; \mathrm{EP}_{3}=1.21$; $\mathrm{EP}_{4}=1.31 ; \mathrm{EP}_{5}=1.52$ and $\mathrm{EP}_{6}=1.63$.

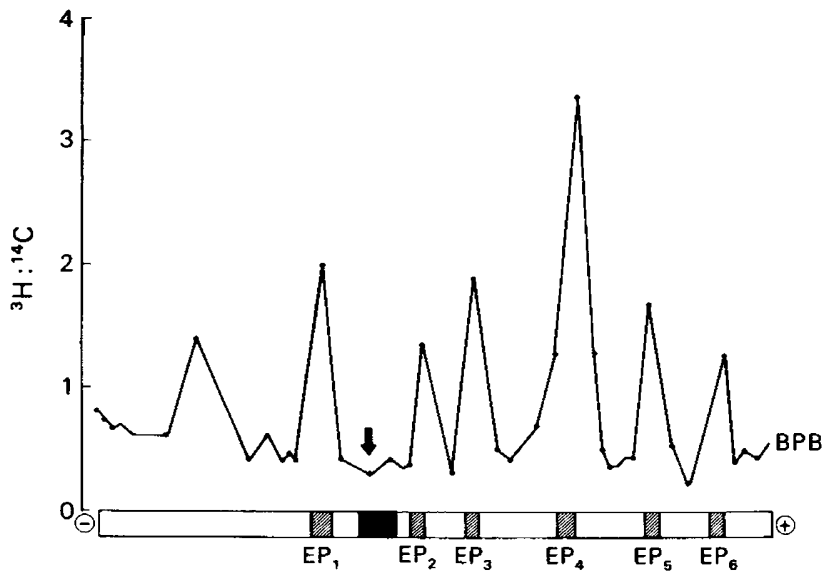

Text-fig. 1. Combined schematic representation (from 9 experiments) of the differential incorporation of labelled amino acid into soluble proteins by the epididymides of castrated (15 days) hamsters with and without androgen treatment. Aliquots (50-100 mg) of epididymal minces were incubated as described in 'Materials and Methods'. After co-electrophoresis in $10 \%$ polyacrylamide gels, the gels were stained or sliced at $1 \mathrm{~mm}$ intervals. The arrow indicates the position of albumin. BPB: bromophenol blue.

Next, the pattern of bands stained by Coomassie Blue in the soluble fraction of the epididymis of control animals was determined (Pl. 1, Fig. 1, Gel A). Comparison with the pattern obtained by electrophoresis of the epididymal cytosol from animals castrated for 15 days (Gel B) showed that there was a marked decrease in intensity of 6 bands with relative mobilities corresponding to those of $\mathrm{EP}_{1}-\mathrm{EP}_{6}$. Administration of testosterone (300 $\mu \mathrm{g} /$ day for 10 days) to animals castrated for 15 days induced an increase in the intensity of the same bands (Gel C). In an attempt to quantify these changes, gels were scanned at $550 \mathrm{~nm}$ in a densitometer and the results indicated that the bands of $\mathrm{EP}_{1}-\mathrm{EP}_{6}$ contributed approximately $37 \%$ to the total soluble protein in control epididymides. This proportion was reduced to $24 \%$ in the 15 -day castrates and restored to $34 \%$ after 10 days of androgen treatment.

The peak of labelled protein found towards the cathode of EP 1 (Text-fig. 1), with $R a 0.40$, did not correspond to a stainable band sensitive to castration in these experiments. On the other hand one of the main bands in the cytosol, $R$ a 0.29 , although sensitive to castration and androgen replacement, as judged by the visual alterations in colour intensity (PI. 1, Fig. 1), did not have a counterpart in the amino acid incorporation studies.

The effect of castration on $\mathrm{EP}_{1}-\mathrm{EP}_{6}$ was manifest 7 days after orchidectomy and intensified with time until all EP bands were práctically undetectable by staining by 45 days after castration. While the effect of castration seemed uniform for all bands, testosterone treatment increased the intensity of bands for $\mathrm{EP}_{1}, \mathrm{EP}_{2}$ and $\mathrm{EP}_{4}$ faster than that of bands for $\mathrm{EP}_{3}, \mathrm{EP}_{5}$ and 
$\mathrm{EP}_{6}$ (PI. 1, Fig. 2). This result is in agreement with the different degree of stimulation of synthesis of epididymal protein suggested by the experiments in Text-fig. 1 in which incorporation of label into $\mathrm{EP}_{1}, \mathrm{EP}_{3}$ and $\mathrm{EP}_{4}$ appeared greater than that into $\mathrm{EP}_{2}, \mathrm{EP}_{3}$ and $\mathrm{EP}_{6}$.

The comparison of the pattern of bands separated by electrophoresis of epididymal cytosol with that of other tissues and fluids, revealed the absence in muscle, liver and serum of components with relative mobilities similar to those of the EP bands. Testis cytosol, however, showed bands with the same relative mobilities as $\mathrm{EP}_{1}$ and $\mathrm{EP}_{4}$ (Pl. 1, Fig. 3), while fluid from the cauda epididymidis was rich in $\mathrm{EP}_{1}, \mathrm{EP}_{3}$ and $\mathrm{EP}_{4}$.

Spermatozoa obtained from the testis and from different segments of the epididymis were treated with 0.25 or $0.5 \mathrm{M}-\mathrm{NaCl}$ to elute the proteins. No bands corresponding to those of the epididymal proteins were eluted from spermatozoa from the testis or proximal segments. However, spermatozoa from the distal corpus and cauda epididymidis contained appreciable

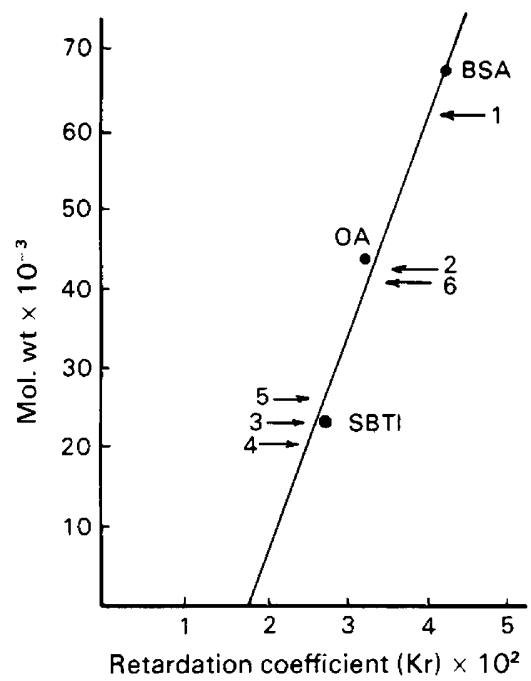

Text-fig. 2. The linear regression method to estimate the molecular weights of the hamster epididymal proteins. The standards were bovine serum albumin (BSA, mol. wt 67000); ovoalbumin (OA, mol. wt 43500 ) and soybean trypsin inhibitor (SBTI, mol. wt 22 700) and the position for each EP band is indicated. The values obtained are the mean of 3 determinations. The coefficient of correlation of the line is $r=0.988$.

\section{PLATE 1}

Fig. 1. Effect of castration and androgen treatment of hamsters upon soluble epididymal proteins (bands $\mathrm{EP}_{1}-\mathrm{EP}_{6}$ ). Aliquots of epididymal cytosol ( $75 \mu \mathrm{g}$ protein) were electrophoresed in $10 \%$ polyacrylamide gels and stained with Coomassie Blue. $\mathrm{A}=$ intact control; $\mathrm{B}=$ castrated for 15 days; $C=$ castrated for 15 days and treated with $300 \mu \mathrm{g}$ testosterone/day for 10 days. The arrow indicates the position of albumin.

Fig. 2. Effect of different periods of castration and androgen replacement upon soluble epididymal proteins. $\mathrm{A}=$ castration for 7 days; $\mathrm{B}=$ castration for 15 days; $\mathrm{C}=$ castration for 30 days; $\mathrm{D}=$ castrated for 30 days and given $300 \mu \mathrm{g}$ testosterone/day for 10 days; $\mathrm{E}=$ same as $\mathrm{D}$ but testosterone given for 15 days; $\mathrm{F}=$ same as $\mathrm{D}$ but testosterone given for 30 days.

Fig. 3. Comparison of protein bands in hamster epididymal (A) and testicular (B) cytosol and in blood serum $(\mathrm{C})$.

Fig. 4. Comparison of protein bands $\left(\mathrm{EP}_{1}-\mathrm{EP}_{6}\right)$ in hamster epididymal cytosol (A, in 0.25 $\mathrm{M}-\mathrm{NaCl}$ ) and in sperm extracts (B-E). Spermatozoa were recovered from the cauda epididymidis (samples from 4 different animals). The arrow indicates the position of albumin. 
PLATE 1
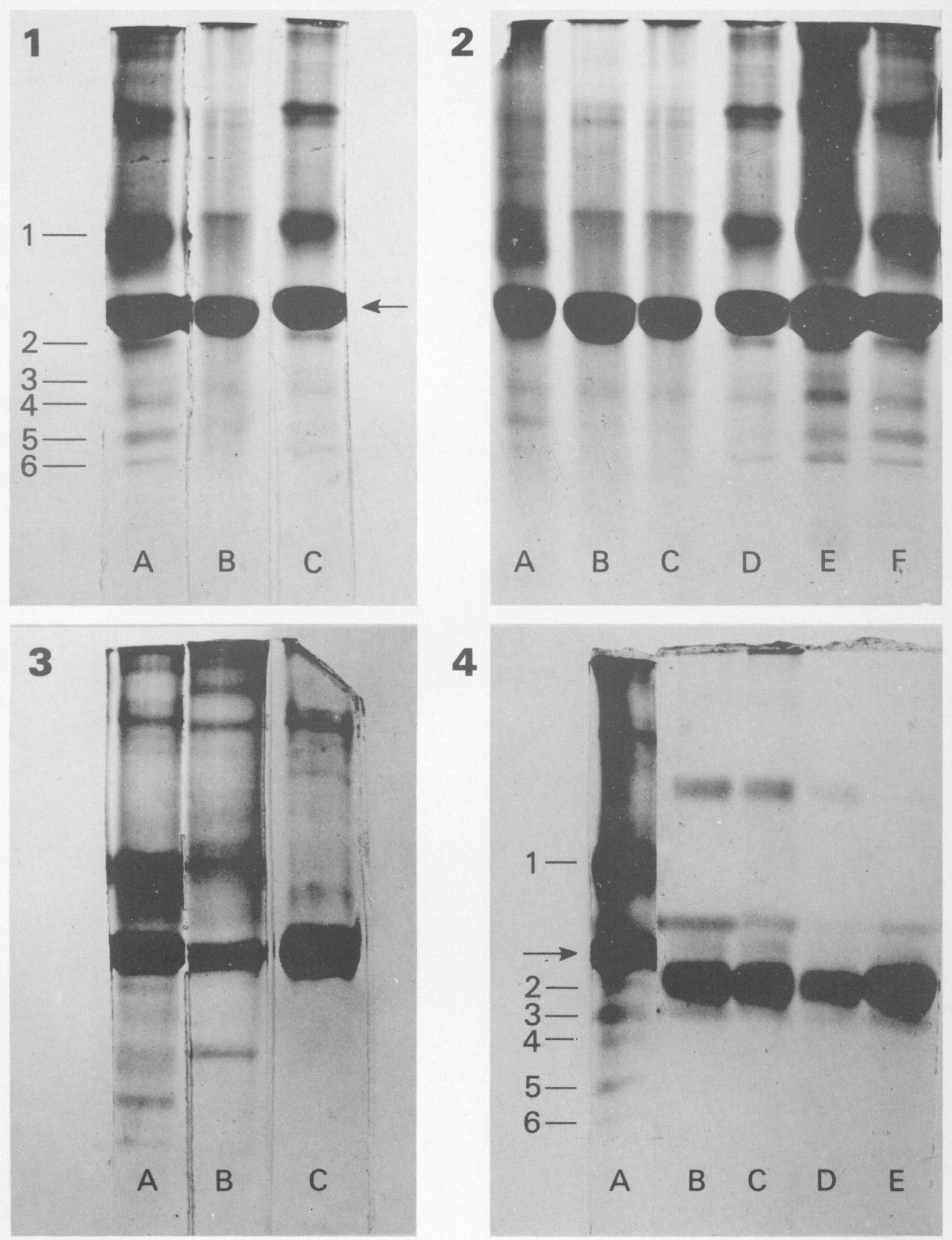

(Facing p. 4) 
amounts of $\mathrm{EP}_{2}$ and $\mathrm{EP}_{3}: 63 \%$ of the total protein eluted by $0.5 \mathrm{M}-\mathrm{NaCl}$ from the cauda spermatozoa was due to $\mathrm{EP}_{2}+\mathrm{EP}_{3}$.

The large amount of $\mathrm{EP}_{2}$ eluted from cauda spermatozoa resembled the relative contribution of albumin to control epididymal cytosol (Pl. 1, Fig. 4). Since EP 2 had an $R$ a of $1 \cdot 1$, it was important to ascertain its identity as distinct from albumin, ignoring the possibility that the saline treatment or the release of proteolytic enzymes from the acrosome during extraction could have altered the electrophoretic mobility of albumin. Cytosol that had been made 0.25 and $0.5 \mathrm{M}$ with respect to $\mathrm{NaCl}$ and incubated for $20 \mathrm{~min}$ was therefore electrophoresed: the mobility of albumin was not altered. Spermatozoa were also extracted in buffer containing $0.25 \mathrm{M}-\mathrm{NaCl}$ and soybean trypsin inhibitor $\left(0.25 \mathrm{mg} / 10^{6}\right.$ cells $)$ : there was no alteration in the mobility of the extracted band during electrophoresis.

The molecular weight of each band was estimated by the linear regression method (Text-fig. 2): the values were 61400 for $\mathrm{EP}_{1}, 42500$ for $\mathrm{EP}_{2}, 23800$ for $\mathrm{EP}_{3}, 20400$ for $\mathrm{EP}_{4}, 26100$ for $\mathrm{EP}_{5}$ and 41000 for $\mathrm{EP}_{6}$.

Staining with the periodic acid-Schiff reagent was positive for bands $\mathrm{EP}_{1}$ to $\mathrm{EP}_{6}$, thus indicating their glycoprotein nature.

\section{Discussion}

Our results demonstrate the existence of androgen-dependent proteins in the hamster epididymis. The two techniques used for the detection of these proteins in this study showed an excellent correlation with respect to bands $\mathrm{EP}_{1}-\mathrm{EP}_{6}$. However, each technique detected one extra band influenced by androgens, one of $R \mathrm{a} 0.40$ (labelled precursor incorporation) and one of $R \mathrm{a} 0.29$ (Coomassie Blue staining), for which the corresponding variation was not observed with the other technique. Possible explanations for this discrepancy may be that the $R$ a 0.40 band represents an amount of protein not detectable by staining, while the protein of $R$ a 0.29 may have a variable concentration in the epididymis through an androgen-controlled mechanism not requiring its de-novo synthesis.

Although the presence of bands with the same mobility as $\mathrm{EP}_{1}$ and $\mathrm{EP}_{4}$ in testicular cytosol might suggest that these proteins pass into the epididymis with testicular fluid, the epididymal origin of the bands examined is demonstrated by their synthesis in the tissue of castrated, androgen-treated animals. The presence of $\mathrm{EP}_{1}, \mathrm{EP}_{3}$ and $\mathrm{EP}_{4}$ in the fluid from the cauda epididymidis indicates the secretory nature of these proteins, while the extraction of $\mathrm{EP}_{2}$ and $\mathrm{EP}_{3}$ from the surface of spermatozoa is indicative of their interaction with spermatozoa. Again, the absence of these two bands in testicular spermatozoa and their production by the epididymis of castrated, testosterone-treated animals attest to their epididymal origin and demonstrate that the presence of spermatozoa is not required for their synthesis.

The interaction of epididymal protein with spermatozoa is the focal point of the present experiments, since our final aim is the identification of the factors that induce the maturation of spermatozoa and of their mode of action. Such interaction has been shown for several species (Cameo \& Blaquier, 1976; Lea et al., 1978; Olson \& Hamilton, 1978; Voglmayr et al., 1980; Moore, 1980) and its biological relevance has been stressed by Orgebin-Crist \& Jahad (1978, 1979).

The elution of epididymal proteins from spermatozoa recovered from the distal corpus and cauda regions, while they were not detected in spermatozoa from proximal segments, is analogous to the observations of Olson \& Hamilton (1978) and Kohane et al. (1980) for the rat, but different from those of Lea et al. (1978), who found acidic epididymal glycoprotein coating spermatozoa in all epididymal segments distal to the proximal caput. However, the gradual attachment of specific epididymal proteins to spermatozoa as they pass along the duct has been demonstrated $\left(151,221\right.$ and $607 \mathrm{U} / 10^{6}$ cells for spermatozoa recovered from caput, corpus and 
cauda epididymidis respectively) (Kohane, González Echeverria, Piñeiro \& Blaquier, 1981). It is possible that a similar phenomenon occurs in the hamster but the techniques used may have prevented the detection of amounts of epididymal protein lower than those accumulated in distal corpus and cauda spermatozoa. The quantitative and qualitative similarity of the proteins eluted from spermatozoa from the cauda epididymidis by 0.25 and $0.5 \mathrm{M}-\mathrm{NaCl}$ suggests that these proteins are loosely bound to the sperm surface.

Although the evidence is still incomplete, our experiments suggest that hamster spermatozoa have acquired their full complement of epididymal protein by the time they reach the proximal cauda region; it is in this region that spermatozoa attain maximal fertilizing capacity (Horan $\&$ Bedford, 1972), as the result of a strictly androgen-dependent maturation process (LubiczNawrocki, 1976).

Comparative analysis of the available data on the molecular weights of the epididymal proteins in different species, reveals the almost constant finding of a protein with a molecular weight in the range $37000-40000$ in association with spermatozoa. The protein eluted from rat spermatozoa by Olson \& Hamilton (1978), Cameo \& Blaquier (1976) and Garberi, Kohane, Cameo \& Blaquier (1979), and that from the bull (Vierula \& Rajaniemi, 1980), weighs 37000. However, Lea et al. (1978) reported an acidic rat protein weighing 40000 and two proteins that interact with ram spermatozoa (Voglmayr et al., 1980) have a molecular weight of 36000 and 40000 . The corresponding moiety in the hamster would be $\mathrm{EP}_{2}$ with an estimated molecular weight of 42500 . This slightly higher value may be due to the fact that, as a glycoprotein, $\mathrm{EP}_{2}$ may present anomalous electrophoretic mobility (Bretscher, 1971) which would introduce error in the molecular weight determination by the method used in this work. The $\mathrm{EP}_{6}$ protein has a closer molecular weight $(41000)$ but it was not detected in sperm extracts.

The second major protein eluted from hamster spermatozoa was $\mathrm{EP}_{3}$ (mol. wt 23000 ), which might be analogous to the protein (mol. wt 24 000) described by Voglmayr et al. (1980) as the most prominent band eluted from ram spermatozoa in the cauda epididymidis and which is also present in fluid from this region of the epididymis, suggesting its secretion by the epithelium. Protein $\mathrm{C}$, the second main component of rat specific epididymal proteins (Cameo \& Blaquier, 1976; Garberi et al., 1979) is associated with spermatozoa and weighs 22000 . Further coincidence between species is found between $\mathrm{EP}_{1}$ (mol. wt 61 400) and proteins interacting with ram (mol. wt 71 000; Voglmayr et al., 1980) and bull (mol. wt 67 000-69 000; Vierula \& Rajaniemi, 1980) spermatozoa. Most of the epididymal proteins discussed above, including those of the hamster and rat, are glycoproteins.

This work was partly supported by grant $780 / 0610$ from the Ford Foundation, and by the National Research Council, Argentina. J.B. is a Research Career Awardee, National Research Council, Argentina.

\section{References}

Barker, L.D.S. \& Amann, R.P. (1971) Epididymal physiology. II. Immunofluorescent analysis of epithelial secretion and absorption and of bovine sperm maturation. J. Reprod. Fert. 26, 319-332.

Bedford, J.M. (1963) Changes in the electrophoretic properties of the rabbit spermatozoa during passage through the epididymis. Nature, Lond. 100, 1178 1180.

Bedford, J.M. (1975) Maturation, transport, and fate of spermatozoa in the epididymis. In Handbook of Physiology, Section 7. Endocrinology, Vol. V, ch. 14, pp. 303-317. Eds D. W. Hamilton \& R. O. Greep. Am. Physiol. Soc., Washington, D.C.

Bretscher, M.S. (1971) Major human erythrocyte glyco- protein spans the cell membrane. Nature, New Biol. 231, 229-232.

Cameo, M.S. \& Blaquier, J.A. (1976) Androgen controlled specific proteins in rat epididymis. J. Endocr. 69, 47-55.

Cooper, G.W. \& Bedford, J.M. (1971) Acquisition of surface charge by the plasma membrane of mammalian spermatozoa during epididymal maturation. Anat. Rec. 169, 300-301.

Garberi, J.C., Kohane, A.C., Cameo, M.S. \& Blaquier, J.A. (1979) Isolation and characterization of specific rat epididymal proteins. Molec. cell. Endocr. 13, $73-82$.

Horan, A.H. \& Bedford, J.M. (1972) Development of the 
fertilizing ability of spermatozoa in the epididymis of the Syrian hamster. J. Reprod. Fert. 30, 417-423.

Hunter, A.G. (1969) Differentiation of rabbit sperm antigens from those of seminal plasma. J. Reprod. Fert. 20, 413-418.

Johnson, W.L. \& Hunter, A.G. (1972) Immunofluorescent evaluation of the male rabbit reproductive tract for sites of secretion and absorption of seminal antigens. Biol. Reprod. 6, 13-22.

Katzenellenbogen, B.S. \& Gorski, J. (1975) Methods for assessing estrogen effects on new uterine protein synthesis in vitro. Methods in Enzymology 36, 444-445.

Killian, G.J. \& Amann, R.P. (1973) Immunoelectrophoretic characterization of fluid and sperm entering and leaving the bovine epididymis. Biol. Reprod. 9, 489-499.

Kohane, A.C., Cameo, M.S., Piñeiro, L., Garberi, J. \& Blaquier, J.A. (1980) Distribution and site of production of specific proteins in the rat epididymis. Biol. Reprod. 23, 181-187.

Kohane, A.C., González Echeverría, F.M.C., Piñeiro, L. \& Blaquier, J.A. (1981) Interaction of proteins of epididymal origin with spermatozoa. Biol. Reprod. 23, 737-742.

Lea, O.A., Petrusz, P. \& French, F.S. (1978) Purification and localization of acidic epididymal glycoprotein (AEG): a sperm coating protein secreted by the rat epididymis. Int. J. Androl., Suppl. 2, 592-605.

Lowry, O.H., Rosebrough, N.J., Farr, A.L. \& Randall, R.J. (1951) Protein measurement with the Folin phenol reagent. J. biol. Chem. 193, 265-275.

Lubicz-Nawrocki, C.M. (1976) The effect of metabolites of testosterone on the development of fertilizing ability by spermatozoa in the epididymis of castrated hamster. J. exp. Zool. 197, 89-95.

Moore, H.D.M. (1979) The net surface charge in mammalian spermatozoa as determined by isoelectric focusing. Changes following sperm maturation, ejaculation, incubation in the female tract and after enzyme treatment. Int. J. Androl. 2, 449-462.

Moore, H.D.M. (1980) Localization of specific glycoproteins secreted by the rabbit and hamster epididymis. Biol. Reprod. 22, 705-718.

Nicolson, G.L., Usui, N., Yanagimachi, R., Yanagimachi, H. \& Smith, J.R. (1977) Lectin-binding sites on the plasma membranes of rabbit spermatozoa. Changes in surface receptors during epididymal maturation and after ejaculation. J. Cell Biol. 74, 950-962.

Olson, G.E. \& Hamilton, D.W. (1978) Characterization of the surface glycoproteins of rat spermatozoa. Biol. Reprod. 19, 26-35.

Orgebin-Crist, M.C. \& Jahad, N. (1978) The maturation of rabbit epididymal spermatozoa in organ culture: inhibition by antiandrogens and inhibitors of ribonucleic acid and protein synthesis. Endocrinology 103, 46-53.

Orgebin-Crist, M.C. \& Jahad, N. (1979) The maturation of rabbit epididymal spermatozoa in organ culture: stimulation by epididymal cytoplasmatic extracts. Biol. Reprod. 21, 511-515.

Orgebin-Crist, M.S., Danzo, B.J. \& Davies, J. (1975) Endocrine control of the development and maintenance of sperm fertilizing ability in the epididymis. In Handbook of Physiology, Section 7, Vol. 5, pp. 319-335. Eds D. W. Hamilton \& R. O. Greep. Am. Physiol. Soc., Washington, D.C.

Rodbard, D. \& Chrambach, A. (1974) Quantitative polyacrylamide gel electrophoresis: mathematical and statistical analysis of data. In Electrophoresis and Isoelectric Focusing in Polyacrylamide Gel, ch. 2, pp. 28-62. Eds R. C. Allen \& H. R. Maurer. Walter de Gruyter, Berlin.

Vierula, M. \& Rajaniemi, N. (1980) Radioiodination of surface proteins of bull spermatozoa and their characterization by dodecyl sulphate-polyacrylamide gel electrophoresis. J. Reprod. Fert. 58, 483-489.

Voglmayr, J.K., Fairbanks, G., Jackowitz, M.A. \& Colella, J.R. (1980) Post-testicular developmental changes in the ram sperm cell surface and their relationship to luminal fluid proteins of the reproductive tract. Biol. Reprod. 22, 655-667.

Yanagimachi, R., Noda, Y.D., Fujimoto, M. \& Nicolson, G.L. (1972) The distribution of negative surface changes in mammalian spermatozoa. Am. J. Anat. 135, 497-520.

Zacharius, R.M., Zell, T.E., Morrison, J.H. \& Woodlock, J.J. (1969) Glycoprotein staining following electrophoresis in acrylamide gels. Analyt. Biochem. 30, 148-161.

Received 6 October 1980 